\title{
An Examination of green HR practices and its impact on environmental sustainability
}

\author{
Aakanksha Uppal, Barkha Kakkar, Yashmita Awasthi
}

\begin{abstract}
After the starting of industrialization in case of manufacturing, the concerned management and even the researchers are looking forward to incorporate some amount of automation so that the human effort can be minimized and the saved energy can be used for innovation and other important tasks. In the present scenario, all over the world the level of automation is highest in all the manufacturing units and it has distorted the very balance of our ecosystem and environment. As and when the respective agencies were able to see and feel it, the damage was done. From the last three decades many of the agencies, which are the well-wishers of both the parties i.e. the manufacturers and the environment protectors. The process started from protecting the emission of harmful gases in the environment and then at the second level strategies were formulated to change the system at the ground level where such events may not occur. Green Human Resource Management (GHRM) Practices is again another such initiative, this may not show a major turnaround but then again the collective efforts will be appreciated in the future. This present paper is focused on the implementation of GHRM practices in the manufacturing units. Some amount of secondary data is being evaluated and analysis is based on primary data. Primary data is taken from the respondents working in $H R$ departments of the sampled companies. SPSS Ver. 20.0 is considered for the analysis of data.
\end{abstract}

Keywords: Green HRM practices, Environment Protection.

\section{INTRODUCTION}

Many of the international agencies had laid down standards for the waste management and manufacturing units all over the world, but in order to produce more and make higher profits most of the manufacturers did considered them or either avoided them. Then in the year 2008 the term 'Green Management' came into existence and the same was supported by some laws and allied regulations. Sudin (2011). In order to sustain and protect the environment many of the international groups and agencies came upfront and the word to save the environment spread very fast. Even there were some of the cases where the customer had denied buying the product which is not manufactured under the prescribed laws. This is a well-known fact that HR is one of the most significant functions of all the management function; it was the last department that received importance under the green drive.

Revised Manuscript Received on November 11, 2019.

* Correspondence Author

Dr.Aakanksha Uppal, Assistant Professor, Symbiosis centre for Management studies, Noida

Ms.Barkha Kakkar, Assistant Professor, Institute of Technology and Science, Mohan Nagar, Ghaziabad

Dr.Yashmita Awasthi, Assistant Professor, Institute of Technology and Science, Mohan Nagar, Ghaziabad
There are a number of researchers who had conducted a trail of studies on the different management functions and impact of the same on the environment as such, but actually there are minimum studies that had considered the importance of HR department and its contribution in the green drive. Most of the studies are based on the process evaluation of recruitment, training and selection even strategic HRM is the part of the same. Hence this calls for more studies to be conducted in this area, and in the lieu of the same this present study can be considered as a special add on to the total trail of research. Renwick et al, 2013. Although some of the studies had pointed out the positive effect of applying green practices in the HR activities of the company.

It is not so that saving the environment is the sole responsibility of the organizations, but there are other stakeholders also who are required to take the responsibility of the same, like customers, suppliers, employees, investors, etc. it can be easily visualized that any of the employee working in a given industrial setup, will be a first person to identify any lacuna in relation to breach environment related regulations. Barry et al (1988). With the development of technological avenues and progress in the information technology most of the stakeholders are becoming aware of the fact that if we are not able to save our environment there will be nothing to save in the future. This phenomenon is spreading very fast and respective HR departments are also paying attention to the same.

If GHRM practices are included in the organization then the efficiency of the workers will be increased, costs can be controlled and even reduced to a certain extent and even the level of employee engagement can be increased. Rani et al (2014). In the present times the interest of researchers is increasing in the development of human resource and a number of studies are being conducted to make them efficient enough to handle the challenges. Then there is another segment of researchers who are emphasizing on the use of such HR practices that are friendly to the environment and the respective studies also stated that the collective impact of such initiatives will benefit the environment in the present and even in the long term. Renwick et al. (2013).

Some of the important components related to GHRM are as follows:

a. Employee performance: as far as GHRM is concerned it is more of an awareness system rather than a practice. Like at the first place such people are recruited 
which are aware of green practices. Once such type of people are hired it becomes easier to train them for the purpose of benefitting the organization in the lieu of green practices. Lefebvre et al (2003). The duty of HR department does not gets over with hiring such people rather it is more important to involve them in the activities of the organization towards the green movement. Jabbour (2012).

b. Green recruitment this is something that is already in practice i.e. the companies are already calling for application over internet and in most of the IT companies and off shore appointments interviews are taken over internet using application like skype, etc. this process is going to stop the use of paper in the recruitment process and in turn the cutting of trees will be reduced and this can be considered as one of the steps to save the environment. On the other hand if the employees are aware about the issues related to harming of environment then they will take care of the same within their work profile and will make other employees aware about the same. Harvey et al (2010).

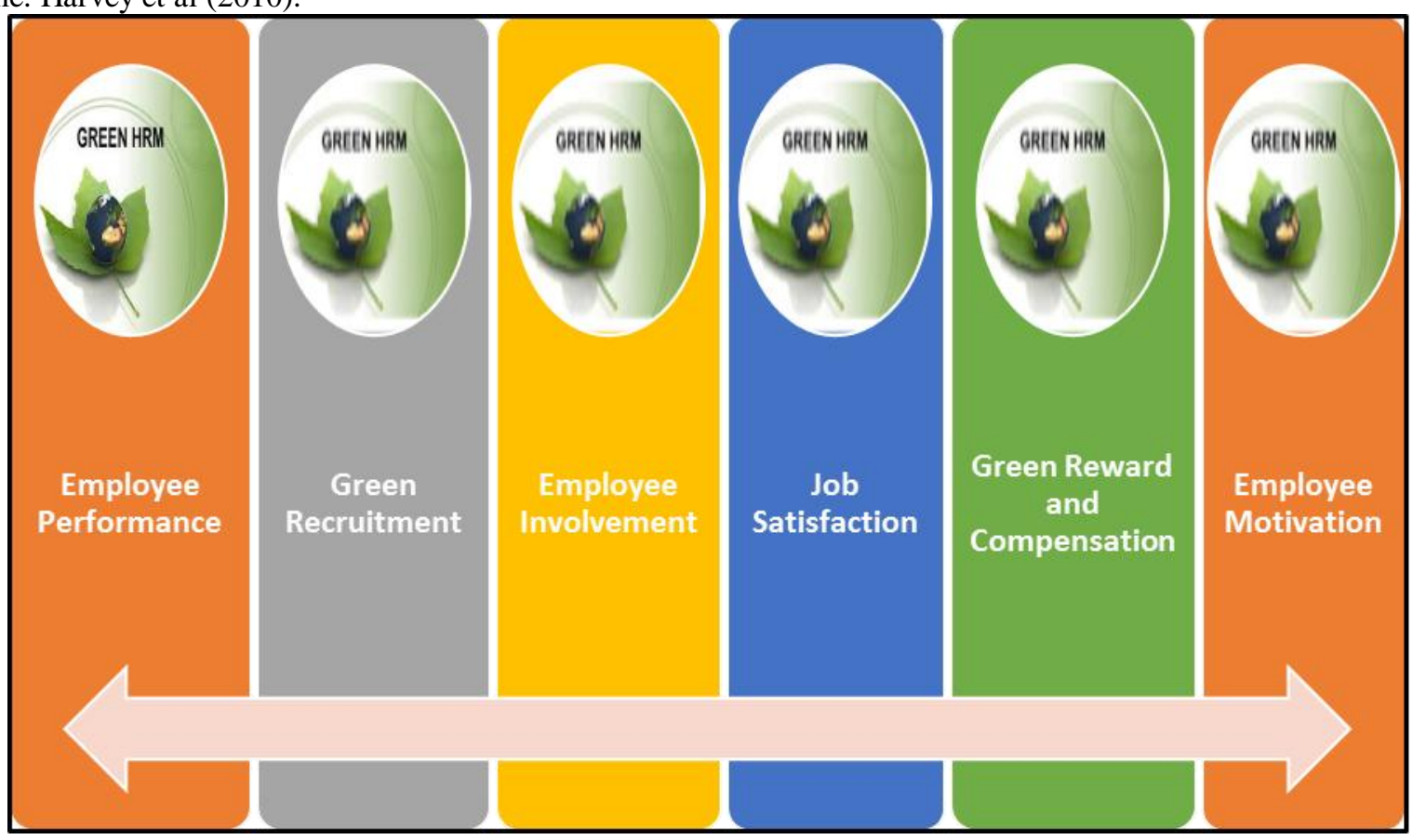

green objectives and are following all the rules and regulations related to the same. Lawler (2008). Apparently such rewards are apart from the regular incentives that an employee uses to receive in the due course of their duties. achievements of the employees within their respective job profiles. Ahmad (2015). Once the employees are having this feeling of job satisfaction they start to believe in the ideology and objectives of the organization and this encourages both the parties i.e. employee and employer at the same level and it becomes easier for the organization to achieve the green goals.

e. Green Rewards and compensation here the term green rewards refers to the initiative of the organization to recognize those employees who are who are willingly working for the achievement of

c. Employee involvement it is a well-known fact that in most of the organizations, the present employees become reluctant about any type of training or new method of working rather if the company is recruiting such a person who is already aware of the green practices then it becomes easier for the managers to involve the same employees in the achievement of green objectives and apparently the same employees may influence other employees to follow the same practices. In such a case the cadre of the employees plays an important role. Remmen et al (2000). The researchers and the HR experts feel just knowing the drill is not enough rather it is important for the managers to inculcate the feeling of satisfaction among the employees so that they can continue to work towards the achievement of green objectives. Mandip (2012).

d. Job Satisfaction as far as Job satisfaction is .

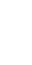


employee can work towards the achievement of organization's goal including the green initiatives. Rothenberg (2003).

\section{LITERATURE REVIEW}

Mandip, 2012: this study was focused on the cost effectiveness in the implementation of green objectives and related continuums. The findings of the study stated that any of the given organization can save the cost while going for green drive rather employees are motivated and understand the benefits of going green. Only a group of motivated employees may push the organization towards success with cost effectiveness.

Alhadid et al 2014: this study was conducted on the manufacturing industries of east Pakistan and evaluates the components related to green practices in the organization. The findings of the study stated that there are only a few organizations in the country which are either in the process of implementing green practices or had already done it. The study also stated that the green practices had already been included in the HR department of the sampled companies, but still there are miles to cover in this regard.

Jackson et al., 2013: the study suggested that if the HR department of any of the given organization is active in understanding the importance of going green, then only the staff side will recognize the importance of the sane and get motivated to act in the same direction. The study also focuses on the training of the employees to exercise green initiatives, the researcher stated that this is the responsibility of the HR department to train the employees about the green initiatives. Margaretha et al 2013: This is a well-known fact that HR is one of the most significant functions of all the management function; it was the last department that received importance under the green drive. With the development of information technology and reduction in the cost of internet, the companies had started calling application over internet and in most of the IT companies and off shore appointments interviews are taken over internet using application like skype, etc. this process is going to stop the use of paper in the recruitment process and in turn the cutting of trees will be reduced and this can be considered as one of the steps to save the environment.

\section{OBJECTIVES}

- To evaluate the importance and implementation scenario of Green HRM practices in IT companies of Chennai.

- To analyze the effectiveness of Green HRM practices.

- To evaluate the impact of Green HRM practices on environment.

\section{HYPOTHESIS}

Hypothesis 1
$\mathrm{H}_{0}$ : There is significant positive relationship between Employee Involvement in Green HRM practices and sustaining the environment.

$\mathrm{H}_{1}$ : There is negative relationship between Employee Involvement in Green HRM practices and sustaining the environment.

\section{Hypothesis 2}

$\mathrm{H}_{0}$ : There is significant positive relationship between Green rewards/compensation and motivation of employees.

$\mathrm{H}_{1}$ : There is negative relationship between Green rewards/compensation and motivation of employees.

\section{RESEARCH METHODOLOGY}

\section{Data Collection}

Present study is based on primary data which was collected by using a structured questionnaire. The type of questions which were included in the questionnaire are scale based, some direct questions and choice based. The companies which were selected for the study are:

- TVS Electronics Ltd.

- ADP India Pvt. Ltd.

- Advantix Technologies

- Agilisium Consulting

Secondary data was collected from various articles, journals, magazines and books relevant for research work.

\section{Sample Size}

The total number of employees in the above companies are approximately 200 each hence $25 \%$ i.e. 50 employees from each company is selected as sample. The researcher had tried to contact especially the employees of HR department

\section{Statistical tools used \\ - Descriptive analysis \\ - Chi Square test.}

\section{DATA ANALYSIS}

\section{For Hypothesis 1}

Components of Employee Involvement: the researcher has chosen only those components that are directly related to the reduction of carbon footprints by any of the HR related activity and where the employees and HR personals are directly involved. Some of such components are as follows:

- Green Printing

- Job Sharing

- Training programs online

- Online Interviews

Then, the above given components are undertaken as parameters of Chi Square $\left(\chi^{2}\right)$ test and are tested on the fixed values of gender and experience. 
Summary of Chi Square $\left(\chi^{2}\right)$ Hypothesis 1

\begin{tabular}{|c|c|c|c|c|c|c|c|c|}
\hline & \multicolumn{8}{|c|}{ Summary of Chi Square test (H1) } \\
\hline & \multicolumn{8}{|c|}{ Green Printing } \\
\hline & \multicolumn{4}{|c|}{ On the basis of Gender } & \multicolumn{4}{|c|}{ On the Basis of Experience } \\
\hline & Equipment & $\begin{array}{c}\text { Adequate } \\
\text { knowledg } \\
\text { e }\end{array}$ & $\begin{array}{c}\text { Not } \\
\text { reluctan } \\
\mathbf{t}\end{array}$ & $\begin{array}{c}\text { Easy to } \\
\text { Learn }\end{array}$ & Equipment & $\begin{array}{c}\text { Adequate } \\
\text { knowledg } \\
\text { e }\end{array}$ & $\begin{array}{c}\text { Not } \\
\text { reluctan } \\
\mathbf{t}\end{array}$ & $\begin{array}{c}\text { Easy to } \\
\text { Learn }\end{array}$ \\
\hline Calculated Value & .159 & .243 & .159 & .063 & .445 & .435 & .053 & .943 \\
\hline \multirow[t]{4}{*}{ Table Value } & 3.67 & 2.827 & 3.67 & 5.537 & 1.621 & 1.664 & 5.878 & 2.860 \\
\hline & \multicolumn{8}{|c|}{ Job Sharing } \\
\hline & \multicolumn{4}{|c|}{ On the basis of Gender } & \multicolumn{4}{|c|}{ On the Basis of Experience } \\
\hline & Equipment & $\begin{array}{c}\text { Adequate } \\
\text { knowledg } \\
\text { e }\end{array}$ & $\begin{array}{c}\text { Not } \\
\text { reluctan } \\
\mathbf{t} \\
\end{array}$ & $\begin{array}{c}\text { Easy to } \\
\text { Learn }\end{array}$ & Equipment & $\begin{array}{c}\text { Adequate } \\
\text { knowledg } \\
\text { e }\end{array}$ & $\begin{array}{c}\text { Not } \\
\text { reluctan } \\
\mathbf{t}\end{array}$ & $\begin{array}{c}\text { Easy to } \\
\text { Learn }\end{array}$ \\
\hline Calculated Value & .035 & .375 & .040 & .168 & .943 & .631 & .703 & .943 \\
\hline \multirow[t]{4}{*}{ Table Value } & 6.705 & 1.962 & 6.436 & 3.571 & 2.860 & 6.145 & 5.504 & 2.860 \\
\hline & \multicolumn{8}{|c|}{ Online Training } \\
\hline & \multicolumn{4}{|c|}{ On the basis of Gender } & \multicolumn{4}{|c|}{ On the Basis of Experience } \\
\hline & Equipment & $\begin{array}{c}\text { Adequate } \\
\text { knowledg } \\
\text { e }\end{array}$ & $\begin{array}{c}\text { Not } \\
\text { reluctan } \\
\mathbf{t} \\
\end{array}$ & $\begin{array}{c}\text { Easy to } \\
\text { Learn }\end{array}$ & Equipment & $\begin{array}{c}\text { Adequate } \\
\text { knowledg } \\
\text { e }\end{array}$ & $\begin{array}{c}\text { Not } \\
\text { reluctan } \\
\mathbf{t}\end{array}$ & $\begin{array}{c}\text { Easy to } \\
\text { Learn }\end{array}$ \\
\hline Calculated Value & .939 & .560 & .687 & .779 & .635 & .070 & .629 & .629 \\
\hline \multirow[t]{4}{*}{ Table Value } & 2.917 & 6.781 & 5.641 & 4.795 & 6.113 & 14.488 & 6.164 & 6.164 \\
\hline & \multicolumn{8}{|c|}{ Online Interviews } \\
\hline & \multicolumn{4}{|c|}{ On the basis of Gender } & \multicolumn{4}{|c|}{ On the Basis of Experience } \\
\hline & Equipment & $\begin{array}{c}\text { Adequate } \\
\text { knowledg } \\
\text { e } \\
\end{array}$ & $\begin{array}{c}\text { Not } \\
\text { reluctan } \\
\mathbf{t} \\
\end{array}$ & $\begin{array}{c}\text { Easy to } \\
\text { Learn }\end{array}$ & Equipment & $\begin{array}{c}\text { Adequate } \\
\text { knowledg } \\
\text { e } \\
\end{array}$ & $\begin{array}{c}\text { Not } \\
\text { reluctan } \\
\mathbf{t} \\
\end{array}$ & $\begin{array}{c}\text { Easy to } \\
\text { Learn }\end{array}$ \\
\hline Calculated Value & .928 & .146 & .575 & .928 & .605 & .575 & .176 & .698 \\
\hline Table Value & 5.745 & 17.101 & 10.47 & 5.745 & 6.378 & 10.473 & 16.353 & 9.053 \\
\hline
\end{tabular}

\section{Interpretation}

As can be seen from the above table of chi square test, in most of the cases the table value is more than the calculated value; this shows that there is a minimum amount of variation in the responses of sample units. In the above analysis, gender and experience are being considered as the basic component of analysis, this is for the reason that to adopt the green practices in the HR department it is necessary that all the participants of the same are aware about basic rules and regulations of green practices. It has also been observed that male and female both are found to be considerate in this respect and they understand the benefits of following green practices and also they know that it is important to save the environment.

Then on the other hand experience is another important parameter, because as the experience of an employee increases he/she becomes more and more aware and this awareness leads to the acceptance of green practices in the routine activities of HR department of the selected companies. Then on the other hand training also plays an important role and with the increasing experience the reluctant behavior of the employee also changes.

\section{RESULT}

On the basis of above chi square analysis and discussion with the respondents it can be said that there is a minimum amount of variation in the responses of sampled employees and in lieu of the same the null hypothesis 'There is significant positive relationship between Employee Involvement in Green HRM practices and sustaining the environment.' can be accepted and the alternate hypothesis can be rejected.

\section{Hypothesis 2}

$\mathrm{H}_{0}$ : There is significant positive relationship between Green rewards/compensation and motivation of employees.

$\mathrm{H}_{1}$ : There is negative relationship between Green rewards/compensation and motivation of employees.

For the above given hypothesis the meaning of Green reward is considered in the manner where the employees are rewarded if they use to follow all the rules and regulation laid by the company, as far as working is involved. Actually the organizations have broken down the Green policy in small segments and had implemented accordingly and this is done with a view that all the employees can understand then and follow them easily. 
International Journal of Recent Technology and Engineering (IJRTE)

ISSN: 2277-3878, Volume-8 Issue-3S3, November 2019

Summary of Chi Square $\left(\chi^{2}\right)$ Hypothesis 2

\begin{tabular}{|c|c|c|c|c|c|c|c|c|}
\hline & \multicolumn{8}{|c|}{ Summary of Chi Square test (H1) } \\
\hline & \multicolumn{8}{|c|}{ Reward system is fair } \\
\hline & \multicolumn{4}{|c|}{ On the basis of Gender } & \multicolumn{4}{|c|}{ On the Basis of Experience } \\
\hline & $\begin{array}{c}\text { Regular } \\
\text { system }\end{array}$ & $\begin{array}{l}\text { Rewards } \\
\text { are } \\
\text { monetary }\end{array}$ & $\begin{array}{c}\text { Equal } \\
\text { distributi } \\
\text { on }\end{array}$ & Recognition & $\begin{array}{c}\text { Regular } \\
\text { system }\end{array}$ & $\begin{array}{c}\text { Rewards } \\
\text { are } \\
\text { monetary }\end{array}$ & $\begin{array}{r}\text { Equal } \\
\text { distribut }\end{array}$ & Recognition \\
\hline $\begin{array}{l}\text { Calculated } \\
\text { Value }\end{array}$ & 623 & 348 & 619 & . 047 & .551 & 481 & .069 & .832 \\
\hline \multirow[t]{4}{*}{ Table Value } & 2.91 & 3.117 & 2.982 & 4.973 & 2.601 & 2.001 & 4.957 & 3.014 \\
\hline & \multicolumn{8}{|c|}{ Performance Management } \\
\hline & \multicolumn{4}{|c|}{ On the basis of Gender } & \multicolumn{4}{|c|}{ On the Basis of Experience } \\
\hline & $\begin{array}{c}\text { Green } \\
\text { Practic } \\
\text { es are } \\
\text { better }\end{array}$ & $\begin{array}{l}\text { Time is } \\
\text { saved }\end{array}$ & $\begin{array}{l}\text { Energy is } \\
\text { saved }\end{array}$ & $\begin{array}{l}\text { Performance } \\
\text { improvement }\end{array}$ & $\begin{array}{c}\text { Green } \\
\text { Practices } \\
\text { are better }\end{array}$ & $\begin{array}{l}\text { Time is } \\
\text { saved }\end{array}$ & $\begin{array}{l}\text { Energy is } \\
\text { saved }\end{array}$ & $\begin{array}{l}\text { Performance } \\
\text { improvement }\end{array}$ \\
\hline $\begin{array}{l}\text { Calculated } \\
\text { Value }\end{array}$ & .192 & .472 & .083 & 216 & .881 & .702 & .692 & .851 \\
\hline Table Value & 5.001 & 2.130 & 5.174 & 4.208 & 3.812 & 5.794 & 4.992 & 3.025 \\
\hline
\end{tabular}

\section{Interpretation}

As can be seen from the above table of chi square test, in most of the cases the table value is more than the calculated value; this shows that there is a minimum amount of variation in the responses of the sample units. In the above analysis, gender and experience are being considered as the basic component of analysis.

As far as the results of the analysis are concerned, there are two parameters of the same i.e. fairness in the reward system and performance management of the employees. On the basis of gender the variation in the in the responses is less and the respondents accepted that there is a particular reward system in their organization and it is fair enough to be accepted. Here it is important to mention that such a reward system is present in only two of the sampled companies and the other companies do not have any practical system of rewarding the employees.

Then on the other hand, the results for the performance management are also positive as most of the male and female employees are aware about the green practices and are minimum reluctant to the steps taken by the organization in this regard. They also believed that the green practices are supportive enough to save time and cost and on the other hand they can improve their respective efficiency for other related tasks.

The above said results are familiar in case of experience as well, and from the level of awareness in high among all the sampled employees, right from the trainees to the executive level employees. Some of the employees considered it as a burden but they also stated that the related benefits of the green practices cannot be avoided. Now here it is important to mention that any type of monetary reward and recognition is able to motivate a given employee to a certain level. It can be inferred from the above given results that the employees are having all the opportunities to get motivated but not in all the sampled organizations. Rather the point can be proved that yes the employees get motivated by the way they are rewarded and recognized.

\section{Result}

On the basis of above chi square analysis and discussion with the respondents it can be said that there is a minimum amount of variation in the responses of sampled employees and in lieu of the same the null hypothesis 'There is significant positive relationship between Green rewards/compensation and motivation of employees.' can be accepted and the alternate hypothesis can be rejected.

\section{CONCLUSION}

As the orientation of this present study suggests that if any of the given organization is applying green practices in different departments then the overall effect will be in the form of cost, saving, increased efficiency, saving energy, etc. and on the other hand the morale and motivation of the employees will also be increased. This is one side of the coin the other side states that if all the manufacturing organizations start using the green practices then there will be a positive effect on the environment and the same will be secured for the generations to come.

It is not so that the drive to save the environment is new in its origin, rather since decades there are a number of environmentalist who had always reminded of the losses which the mankind is making to the environment, but the development of infrastructure and profit making orientation of the manufacturing concerns never gave a second thought towards the prevention of environment.

As the saying goes "Better Late Than Never", this is the high time for whole of the humanity to take corrective action towards the prevention of the environment and in lieu of the same this study entails the benefits of using green practices even in the HR department of the given organizations. As this present study is based on the evaluation of IT and ITES companies and it is assumed that such companies are already using the green practices in the recruitment process, training process and even in the interviews.

The results of the study stated that there is a high level of acceptance of green practices in the department, irrespective of gender, income level and experience of the employee in (in totality and in the present organization). Then on the second level it is found that most of the employees are aware of the threats and opportunities associated with the greed practices. Here it is important to mention that keep the 
employees motivates is another requirement to get the positive results from the application of green practices in the HR department.

\section{REFERENCES}

1. Pinzone, M.; Guerci, M.; Lettieri, E.; Redman, T. (2016) Progressing in the change journey towards sustainability in healthcare: The role of "Green" HRM. J. Clean. Prod., 122, 201-211.

2. Jabło ' nski, (2016) A. Scalability of Sustainable Business Models in Hybrid Organizations. Sustainability, 8, 194.

3. Zoogah, D. (2011) The dynamics of Green HRM behaviors: A cognitive social information processing approach., 25, 117-139.

4. Gholami, G.; Rezaei, G.; Saman, M.Z.M.; Sharif, S.; Zakuan, N. (2016) State-of-the-Art Green HRM System: Sustainability in the Sports Center in Malaysia Using a Multi-Methods Approach and Opportunities for Future Research. J. Clean. Prod., 124, 142-163.

5. Mazur, B. (2015) Sustainable Human Resource Management. The attempt of holistic approach. Econ. Manag, 7, 7-12.

6. Kim, A.; Kim, Y.; Han, K.; Jackson, S.E.; Ployhart, R. (2017) multilevel influences on voluntary workplace green behavior: Individual differences, leader behavior, and coworker advocacy. J. Manag., 43, 1335-1358.

7. Renwick, D.W.S.; Redman, T.; Maguire, S. (2008) Green HRM: A Review, Process Model, and Research Agenda. University of Sheffield Working Paper. Volume 1, pp. 1-46.

8. Allen, D.G., Shore, L.M., \& Griffeth, R.W. (2003), The role of perceived organizational support and supportive human resource practices in the turnover process, Journal of Management, Vol. 29 No. 1, pp. 99-118.

9. Chaudhary,N., and Sharma,B. (2012), Impact of employee motivation on performance (productivity) In private organization, International Journal Of Business Trends And Technology, Vol 9.

10. Gill Mandip, (2012), Green HRM: People Management Commitment to Environmental Sustainability, Research Journal of Recent Sciences, Vol. 1.

11. Green Human Resource Management: Policies and practices, Shoeb Ahmad, Cogent Business \&Management (2015), Vol2. 15. Govindarajulu, N. and Daily, B.F. (2004), Motivating employees for environmental improvement. Industrial Management and Data Systems, Vol. 104, pp. 364-372.

12. Muhammad Ikhlas Khan, (2012), The Impact of Training and Motivation on Performance of Employees, Business Review - Volume 7 Number 2.

13. Renwick, D. W.S., Redman, T., \& Maguire, S. (2013). Green Human Resource Management: A review and research agenda. International Journal of Management Reviews, Vo1 15 No. 1, pp. 1-14.

14. Sushma Rani and Dr. K. Mishra, (2014), Green HRM: Practices and Strategic Implementation in the Organizations, International Journal on Recent and Innovation Trends in Computing and Communication, Vol.2.

15. Yasamis, F., (2011). Economic instruments of environmental management. Journal of academy and ecology of environmental sciences Vol. 2, pp. 97-111 